\title{
Implementation of Public Employment Services in a Philippine Local Government Unit
}

\author{
Elma B. Bachita ${ }^{1}$ and Ma. Johanna Ann R. Bayoneta ${ }^{2}$ \\ ${ }^{1}$ Local Government Unit of Kabankalan City \\ Negros Occidental, Philippines \\ 2Bacolod City College, Bacolod City, Philippines
}

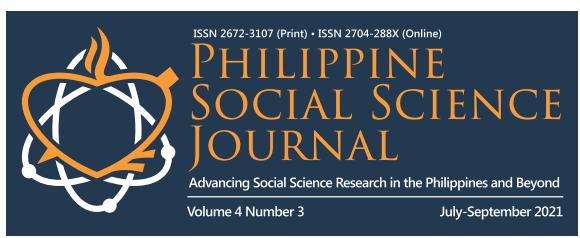

\section{Article history:}

Submitted: 12 August 2021

Revised: 28 September 2021

Accepted: 25 October 2021

\section{Keywords: \\ Public administration \\ Public employment services \\ Descriptive-comparative \\ Local government unit \\ Philippines}

ABSTRACT. The Public Employment Service Office is responsible for implementing labor market programs to promote full employment and equality of employment services. This study assessed the level of implementation of the services of the public employment service office of a component city in the areas of local employment in terms of labor market information, referral and placement, career and employment coaching, provision of livelihood and employment programs, and special employment in terms of reintegration assistance, employability enhancement, pre-employment counseling, and other services as assessed by local and overseas jobseekers and local business and overseas employment agencies. It also investigated the challenges encountered by the respondents in availing these services. This descriptive-comparative study used a researcher-made survey instrument administered to randomly selected local and overseas job seekers and local and overseas business and employment agencies. Using descriptive and inferential analysis, the study yielded a very high level of implementation which implies that the services by the PESO promoted job generation and addressed unemployment although, a significant difference was revealed in the implementation of labor market information and self-employment programs and services. The study recommended the enactment of local laws to enhance employment facilitation.

\subsection{Introduction}

The Public Employment Service Office is responsible for implementing various labor market programs (International Labor Organization [ILO], 2021), which became more important because worldwide, the unemployment rate is rising as nations' economies continue to be affected by the pandemic. Future jobs will differ in the ASEAN because of shifting labor markets; hence, job requirements demand more complex and sophisticated skills (Barr \& Attrey, 2017). In the Philippines, RA 10691 was enacted, amending RA 8759, otherwise known as "The Public Employment Service Act," which mandated the creation of the public employment service office in local governments to promote full employment and equality of employment opportunities (Congress of the Republic of the Philippines, 2017).

Meanwhile, Negros Occidental (Nicavera, 2021) has reported massive unemployment and displacement of workers in both the labor and business sectors due to the pandemic. The city has enacted Ordinance Number 2017-004 under RA 10691 entitled "An Ordinance creating a department in the local government known as the Public Employment Service Office (PESO) to address unemployment. The PESO provided employment opportunities to jobseekers through various local and overseas recruitment activities facilitated by local business establishments and overseas employment agencies. From 2017 to 2020, data showed a low placement turn-out, which motivated this researcher to conduct this study.

Several studies have been conducted on public employment services, such as the study of Nunn (2012) on the management of public service employment in Europe; Weishaupt (2011) on how PES is governed in six European countries; and Behrenz et al. (2013) on cost-benefit and productive efficiency analysis of PES in the European Union. In the Philippines, Sinha (2013) conducted a review on the changing trends of recruitment practices, while Roldan (2020) examined return migrants' entrepreneurship as a development policy, and Fonseca (2015) investigated practices in reintegration. Of the studies reviewed, no study was conducted on implementing employment services in a local government unit that focused on local and overseas employment, hence a gap in the literature.

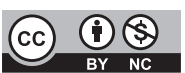

This article published by Philippine Social Science Journal (PSSJ) is licensed under a Creative Commons AttributionNoncommercial 4.0 International (CC BY-NC 4.0). You are free to share (copy and redistribute the material in any medium or format) and adapt (remix, transform, and build upon the material). Under the following terms, you must give appropriate credit, provide a link to the license, and indicate if changes were made. You may do so in any reasonable manner, but not in any way that suggests the licensor endorses you or your use. You may not use the material for commercial purposes. 
This study assessed the level of implementation of the services of the Public Employment Service Office (PESO) of a local government unit in the areas of local employment in terms of labor market information, referral and placement, career and employment coaching, and provision of livelihood and self-employment and other services as assessed by local jobseekers and local business establishments. It also looked into special employment in terms of reintegration, employment assistance, employability enhancement training, pre-employment counseling, and other services as assessed by overseas jobseekers and overseas employment agencies. The study also investigated the challenges encountered by the respondents to avail employment services. The findings of this study may be utilized as the basis of an action plan to improve the services of the PESO in a local government unit.

\subsection{Framework of the Study}

This study theorized that the implementation of public employment services would promote job generation and address unemployment. Equal employment opportunities will raise the standard of living and improve the quality of life for city constituents as it is the governments' key strategy for improving employability (Yap \& Watene, 2019).

The study is anchored on the Theory of Strong Sustainable Development by Shi et al. (2019), which states that decent work and economic growth should achieve economic and social transformation goals, thereby alleviating poverty and promoting economic development. The theory also espoused that natural capital plays an irreplaceable role in economic development. Development requires an increase in the total amount of capital and the rationality of the capital structure, which promotes strong, sustainable development through employment generation.

This theory is appropriate because the strategies of strong, sustainable development characterized by economic and social dimensions (Cyrek \& Fura, 2019) shaping employment structures facilitated the discovery of the level of implementation of employment services and the challenges encountered by respondents in local governments. Further, when the economy of a country fails, this will create problems and cause social instability. Hence government should practice good governance to sustain economic development thru creating employment opportunities and improving employability.

The implementation of employment services thru good governance represented by the provision of livelihood and self-employment programs, transparency, in the labor market information services, and participation of respondents, in referral, placement, employment coaching, and other services implemented by the PESO were applied in the assessment of the implementation of employment services whether it had addressed unemployment and used employment generation to break the intergenerational cycle of poverty, which is one of the primary goals of the theory of strong, sustainable development.

The assessment of the contributions of the different services undertaken by the local PESO determined if these services are responsive to the needs of the respondents. It was also generated from the challenges by applying good governance practices as a component of sustainable development theory as revealed by the respondents in availing of the services implemented by the PESO.

\subsection{Methods}

This is a descriptive-comparative study using a survey questionnaire in the gathering of primary data. A descriptive design was utilized to describe the level of implementation of local and special employment services and the challenges encountered in availing of these services. Descriptive research was appropriate in this study as it aimed to describe a situation in a given state of affairs in terms of the specified variables (Johnson \& Kuby, 2011). The study also utilized the comparative design to determine the differences in the level of implementation of employment services when respondents are grouped as to designation. The comparative design is appropriate as it allows the researcher to examine the differences and similarities between the assessment of the two groups of respondents (the local jobseekers and local business establishments on the implementation of local employment services (Esser \& Vliegenthart, 2017.

The respondents of the study were the 155 PESO clients of a city in Negros Occidental registered in the office representing jobseekers and representatives of local establishments and overseas employment agencies that conduct recruitment activities in the local government unit identified 
through stratified random sampling methods. A researcher-made survey questionnaire based on the provisions of the implementing rules and regulations of RA 10691 was designed to gather primary data. Two sets of instruments were used; Set A was for local job seekers and representatives of local establishments, while Set B was for overseas job seekers and representatives of overseas employment agencies. The survey instrument consists of two parts each. Part I is the profile of the respondents, while Part II contains Likert-type survey questions to measure the level of implementation of local and special employment services of the PESO. Part III is a checklist of challenges encountered by respondents in availing the services of the PESO.

Since the survey instrument used was researcher-made, it underwent the necessary validity and reliability tests. The validity test was performed by a jury of five experts from the Department of Labor and Employment (DOLE) using the criteria of Good and Scates. The suggestions of the members of the jury formed part of the survey instruments. The validity scores were 4.775 for Set $A$ and 4.775 for Set B, signifying that the questions were valid. For the instrument's reliability, it was pilot tested on 30 randomly picked persons who resembled the respondents but were not actual respondents of the study. Cronbach Alpha was used to compute the reliability score resulting in 0.974 for Set A and 0.965 for Set B; both were interpreted as very reliable.

The level of implementation was measured on a scale of 1 to 5 . The highest point in the rating scale was 5 , which was interpreted as very high, which means that the PESO services are excellent. Meanwhile, the lowest was 1 , which was interpreted as very poor implementation.

Before conducting the study, the researcher secured permission and approval from the Local Chief Executive, supervisors of local establishments, and managers of overseas employment agencies through a letter explaining the purpose of the study. With permission granted, the survey questionnaires were administered through the help of enumerators. An orientation via zoom was conducted with the enumerators to ensure the accuracy of gathering the information and the observance of the health protocols. The data gathering was conducted from May 15 to June 15, 2021. After collecting the instrument, the data were encoded, processed, and sent to the statistician for analysis.

Descriptive analysis using the mean and standard deviation was employed to determine the level of implementation of the PESO services in terms of local and special employment services. Descriptive analysis was also used to determine the challenges encountered in availing the PESO services using frequency count and percentage distribution. Comparative analysis used the MannWhitney $\mathrm{U}$ test to determine the differences in local and special employment services implementation because the Kolmogorov Smirnov tests revealed that the variable implementation is not normally distributed, hence the used of non-parametric statistical tools.

Meanwhile, the researcher addressed the general ethical principles of respect for persons, beneficence, and justice to ensure the ethical soundness of the study.

\subsection{Results and Discussion}

\section{Level of implementation of local employment services}

Table 1 shows the level of implementation of the local employment services of the PESO as a whole is very high $(M=4.34 ; S D=0.53)$. When respondents were grouped according to the designation, the local job seekers rated the level of implementation as very high $(M=4.37 ; S D=0.55)$, the same as local business establishments that also rated very high $(M=4.22$ : $S D=0.44)$, although local business establishments rated some services high only.

The overall finding that implementation of local employment services is very high is attributed to local job seekers' rating for all local employment services with a very high implementation. This implies that the services are regularly conducted, made available for job seekers, and benefit the local business establishments. It indicates the functionality of government service for the people; this implies that the PESO thoroughly performs its mandated functions as an employment center. Further, it is an indicator that the respondents are consciously aware of the PESO services conducted through an array of job creation programs that include job fairs and summer job programs organized by the PESO annually, opening job opportunities for many job seekers (Yap \& Watene, 2019) for improving employability. Business establishments rated some services such as labor market information, career, and employment coaching, and self-employment and livelihood programs as high only because they do not directly avail of these services; however, they also reap benefits from these services. 
Table 1. Level of Implementation of the Local Employment Services of the PESO

\begin{tabular}{|c|c|c|c|c|c|c|c|c|c|c|}
\hline & \multirow[t]{2}{*}{ Variable } & \multicolumn{3}{|c|}{$\begin{array}{c}\text { Local } \\
\text { Jobseeker }\end{array}$} & \multicolumn{3}{|c|}{$\begin{array}{c}\text { Business } \\
\text { Establishment }\end{array}$} & \multicolumn{3}{|c|}{ As a Whole } \\
\hline & & $M$ & SD & Int & $M$ & SD & Int & $M$ & SD & Int \\
\hline 1. & $\begin{array}{l}\text { Labor Market } \\
\text { Information Services }\end{array}$ & 4.32 & 0.63 & VH & 4.03 & 0.53 & $\mathrm{Hi}$ & 4.27 & 0.62 & $\mathrm{VH}$ \\
\hline 2. & $\begin{array}{l}\text { Referral and Placement } \\
\text { Services }\end{array}$ & 4.36 & 0.65 & $\mathrm{VH}$ & 4.34 & 0.48 & VH & 4.36 & 0.62 & $\mathrm{VH}$ \\
\hline 3. & $\begin{array}{l}\text { Career and Employment } \\
\text { Coaching Services }\end{array}$ & 4.31 & 0.62 & VH & 4.15 & 0.61 & $\mathrm{Hi}$ & 4.28 & 0.62 & $\mathrm{VH}$ \\
\hline 4. & $\begin{array}{l}\text { Provision of Livelihood } \\
\text { and Self-Employment } \\
\text { Programs and Services }\end{array}$ & 4.41 & 0.60 & VH & 4.00 & 0.69 & $\mathrm{Hi}$ & 4.34 & 0.63 & $\mathrm{VH}$ \\
\hline \multirow[t]{2}{*}{5.} & Other Services & 4.41 & 0.58 & $\mathrm{VH}$ & 4.55 & 0.35 & $\mathrm{VH}$ & 4.43 & 0.54 & $\mathrm{VH}$ \\
\hline & As a whole & 4.37 & 0.55 & $V H$ & 4.22 & 0.44 & $V H$ & 4.34 & 0.53 & $\mathrm{VH}$ \\
\hline
\end{tabular}

Note: $\mathrm{Hi}=$ High, $\mathrm{VH}=$ Very High

Labor market information is characterized by imperfect information (Suarez et al. 2019); hence, it was rated high only, same with career and employment coaching because of the rapidly evolving labor market (Karr et al. 2020), which demands partnership with the academe, civil society, and the private sector found to be deficient in the services of the PESO. Meanwhile, self-employment and livelihood programs were also rated high only as they are linked to the labor market (Kluve et al., 2016), which were found to be not sustainable due to a lack of funds from local governments. The annual job search and placement services make them part of the network of government, which has created demand in other sectors (Caponi, 2017), private and non-government providers involved in addressing the government's economic goals through jobs generation.

The study of the International Labor Organization (2020) and Scarpetta et al. (2020) support the finding that creating opportunities for steady employment is an obligation of the government through public employment services. Karnani (2011) provides additional support, having concluded that creating opportunities for steady employment is the best way to reduce poverty by creating opportunities for steady employment achieved through generating employment, increasing employability, and making the labor market more efficient. Cruz (2014) also substantiates the study's positive results that the government's advocacy career program is an effective tool in addressing job-skills mismatch. The very high implementation of labor market information and referral and placement services find support in the study of Anand et al. (2018) on the effectiveness of recruitment and its processes using labor market information, which substantiates further the importance of recruitment through other sources like schools, walk-ins, and placement services, which are also the same job-generating activities implemented by the PESO.

\section{Level of implementation of special employment services}

In Table 2, the level of implementation of the special employment services of the PESO as a whole is very high $(M=4.49 ; S D=0.40)$. When respondents were grouped according to the designation, the overseas job seekers rated the level of implementation as very high $(M=4.52: S D=0.41)$, the same as the overseas employment agencies that also rated it very high $(M=4.43 ; S D=0.39)$. For job seekers, the highest is reintegration assistance $(M-4.64 ; S D=0.41)$, while for employment agencies, the highest is other services $(M=4.47 ; S D=0.46)$. The lowest rated service for overseas job seekers is employability enhancement $(M=4.32 ; S D=0.55)$, while for overseas employment agencies, the lowest-rated service is pre-employment/occupational counseling $(M=4.33 ; S D=0.49)$.

The findings demonstrate that the functions performed by the PESO in assisting returning Overseas Filipino Workers (OFWs) facilitate the productive return of the OFWs to their families and communities (Fonseca et al., 2015). Returning OFWs who were sent home because of problems with their employers or victims of illegal recruitment can avail of livelihood assistance to help support their reintegration into their families and community (Bachtiar \& Prasetyo, 2014). The PESO implements the service in coordination with national government agencies (Wickramasekara, 2019). 
Table 2. Level of Implementation of the Special Employment Services of the PESO

\begin{tabular}{|c|c|c|c|c|c|c|c|c|c|}
\hline \multirow[t]{2}{*}{ Variable } & \multicolumn{3}{|c|}{$\begin{array}{l}\text { Overseas } \\
\text { Jobseeker }\end{array}$} & \multicolumn{3}{|c|}{$\begin{array}{c}\text { Overseas } \\
\text { Employment Agencies }\end{array}$} & \multicolumn{3}{|c|}{ As a Whole } \\
\hline & $M$ & SD & Int & $\mathrm{M}$ & SD & Int & $M$ & SD & Int \\
\hline $\begin{array}{l}\text { 1. Reintegration } \\
\text { Assistance Services }\end{array}$ & 4.72 & 0.38 & $\mathrm{VH}$ & 4.47 & 0.46 & VH & 4.64 & 0.41 & $\mathrm{VH}$ \\
\hline $\begin{array}{l}\text { 2. Employability } \\
\text { Enhancement }\end{array}$ & 4.32 & 0.55 & $\mathrm{VH}$ & 4.38 & 0.49 & $\mathrm{VH}$ & 4.34 & 0.53 & $\mathrm{VH}$ \\
\hline $\begin{array}{l}\text { 3. Pre- } \\
\text { Employment/Occupati } \\
\text { onal Counselling }\end{array}$ & 4.38 & 0.54 & $\mathrm{VH}$ & 4.33 & 0.49 & $\mathrm{VH}$ & 4.36 & 0.51 & $\mathrm{VH}$ \\
\hline 4. Other Services & 4.67 & 0.38 & VH & 4.53 & 0.46 & $\mathrm{VH}$ & 4.63 & 0.41 & $\mathrm{VH}$ \\
\hline As a whole & 4.52 & 0.41 & $\mathrm{VH}$ & 4.43 & 0.39 & VH & 4.49 & 0.40 & $\mathrm{VH}$ \\
\hline
\end{tabular}

These are some of the needs of returning OFWs that the PESO has been responding to through the implementation of special employment services. The very high level of implementation of special employment services by the PESO affirms the importance and significance of the OFW sector to the economy. The connection between migration and development has been recognized by the Philippine government in the enactment of RA 8042, "Migrant Workers and Overseas Filipinos Act," which provides for full protection of Filipino labor.

The high level of implementation of special employment services is strengthened in the study of the OECD (2017) that public employment services are important in government efforts to tackle unemployment and boost overall employment outcomes.

The study of Fonseca et al. (2015) states that reintegration is an essential part of return migration as it empowers and protects returnees by providing them with tools and assistance for their coming back to society, thereby empowering them to participate again in the social, cultural, economic, and political life. This present finding points to the study of Wickramasekara (2019) that government provides assistance programs even to undocumented OFWs by giving them start-up business capital. While pre-employment/occupational counseling was rated the lowest, it was still interpreted as very high. This finding is validated in the study of Vehkasalo (2020) that the fiscal cost of shifting from face-to-face contacts to online counseling outweighs the fiscal benefits by a large margin.

The study of Angel-Urdinola et al. (2012) recommends improving counseling through groupbased activities, such as collective sessions on local and regional market information, job counseling about skills and qualifications to increase employability, and job skills training programs such as drafting job applications and job interviews.

\section{Difference in the level of implementation of the local employment services}

Mann-Whitney $U$ test was used to determine the significant difference in the implementation of local employment services of the PESO. There is no significant difference in the level of implementation of local employment services of the PESO in the areas of referral and placement services [ $U=997.0, p=0.626]$, career and employment coaching services $[U=894.5, p=0.234]$, and other services [ $U=969.0, p=0.543]$, while there is a significant difference in labor market information $[U=753.5, p=0.030]$ and self-employment programs and services $[U=674.5, p=0.014]$ with job seekers rating higher than business establishments.

This finding implies that local job seekers have availed of referral and placement, career and employment counseling, and other services more than business establishments did because the programs and activities of the local PESO focused on the creation of jobs and opening job opportunities for improving employability (Yap \& Watene, 2019) consistent with the mandates of the "Public Employment Service Act" of the Republic of the Philippines. In contrast, the significant difference in the areas of labor market information is explained by the imperfect information (Suarez et al. 2013) and self-employment programs geared towards local job seekers without the participation of business establishments being an obligation of local governments (Scarpetta et al. 2020). 
Table 3. Difference in the Implementation of Local Employment Services as

Assessed by Jobseekers and Business Establishments

\begin{tabular}{lll}
\hline Variable & $U$ & $\mathrm{p}$ \\
\hline Labor Market Information Services & $753.5^{*}$ & 0.030 \\
Referral and Placement Services & 997.0 & 0.626 \\
Career and Employment Coaching Services & 894.5 & 0.234 \\
Provision of Livelihood and Self-Employment Programs & $674.5^{*}$ & 0.014 \\
and Services & 969.0 & 0.543 \\
Other Services & 840.0 & 0.120 \\
Implementation & &
\end{tabular}

\section{Difference in the level of implementation of special employment services}

Mann-Whitney $U$ test was used to determine the significant difference in the level of implementation of special employment services of the PESO. There was no significant difference in the level of implementation of special employment services as a whole $[U=77.0, p=0.673]$ and in the areas of reintegration assistance services $[U=61.0, p=0.207]$, employability enhancement $[U=82.0$, $p=0.861]$, pre-employment/ occupational counseling $[U=79.0, p=0.743]$, and other services $[U=69.5$, $\mathrm{p}=0.410$ ] which means that when respondents were a group as to designation, their appreciation of the implementation of these services are the same. The absence of significant difference is validated in the challenges encountered by overseas jobseekers and employment agencies in their identification of very minimal challenges, especially by overseas employment agencies, which implies that implementation of the employment services by the PESO is actually very high.

Table 4. Difference in the Level of Implementation of the Special Employment Services as assessed by Overseas Jobseekers and Overseas Employment Agencies

\begin{tabular}{lll}
\hline Variable & $U$ & $p$ \\
\hline Reintegration Assistance Services & 61.0 & 0.207 \\
Employability Enhancement & 82.0 & 0.861 \\
Pre-Employment/ Occupational Counselling & 79.0 & 0.743 \\
Other Services & 69.5 & 0.410 \\
Implementation & 77.0 & 0.673 \\
\hline
\end{tabular}

\section{Challenges encountered in availing the services of the PESO}

Table $5 \mathrm{~A}$ presents the challenges encountered by local job seekers in implementing local employment services by the PESO.

The major challenges under local employment services are: only high-skilled vacancies are available; a range of processes and quality measures needs a long period of time; many requirements are needed to avail of start-up business capital; not aware of NGO livelihood programs, and recruiters charging fees for the services.

Considering that the majority of the local job seekers are confronted with the problem that only high-skilled vacancies are available implies a shortage of skilled workers or a lack of available jobs for unskilled workers and job mismatch.

The shortage of talent and skilled workers to fill job vacancies has become a problem for many industries (Ravelo 2019), such as skills needed in the construction industry. Another problem is the demand for skilled labor in service sectors, and foreign investors (Chemsripong, 2016) confirmed a shortage of professionals and technicians and unskilled and semi-skilled labor. The findings of Foster-McGregor et al. (2013) likewise found that medium-skilled workers have suffered to a greater extent than other skills types in the offshoring of labor demand.

Another implication of the major challenge of only high-skilled vacancies are available is due to job mismatch (Lichy \& Khvatova, 2019) and (DOLE, 2014); the knowledge and skills of job seekers do not match the needs of the companies. Hence, this is the reason for the jobs-skills matching program of the TESDA and DOLE and a requirement imposed by the CHED and DepEd to review academic curricula to provide courses that will arm students with the skills apt for vacant jobs. This is likewise congruent to recent findings of education-job mismatch; specifically, a lack of transferrable 
skills mismatch between the provision of skills development in higher education and the needs of recruiters (Lichy \& Khvatova, 2019). The joint study of the World Bank and the International Labor Organization (2013) also revealed that $36 \%$ of firms reported the lack of pertinent skills as the main reason to fill vacancies. Likewise, it points to the findings of Phaphuangwittayakul et al. (2018) that many graduate students do not have the necessary skills required by the employers.

With technological change, IT skills are also an essential part of a bundle of skills that job seekers must possess. The study findings of Patacsil and Tablatin (2017) revealed that teamwork and communication are important soft skills. In addition, hard skills (technical), like knowledge of standard applications, computer hardware, and networking, were a top-rank student and industry rating. Findings suggest enriching the soft skills and entry-level hard skills component in the curriculum and document processing and hardware operation and maintenance skills basic to a customer-oriented office.

The challenge "a range of process and quality measures need a long period of time" with a frequency count of 30 out of 119 total respondents, or $25.2 \%$ reinforced the study of Cruz (2014) on the need for career guidance advocacy programs to enhance the employability of at-risk youth to improve their integration into productive employment. Furthermore, the study of Karr et al. (2020) points out the need for policymakers to work with the academe, civil society, and private sector to explore partnerships to foster skills training responsive to the needs of the labor market.

Table 5. Challenges Encountered by Local Jobseekers on the Implementation of the Services of the Public Employment Service Office

\begin{tabular}{|c|c|c|c|}
\hline Challenge & & $f$ & $\%$ \\
\hline 1. & Only high-skilled vacancies are available. & 29 & 29.9 \\
\hline 2. & $\begin{array}{l}\text { A range of processes and quality measures need a long } \\
\text { period of time. }\end{array}$ & 29 & 29.9 \\
\hline 3. & $\begin{array}{l}\text { There are recruiters who charge local employment services } \\
\text { for a fee. }\end{array}$ & 24 & 24.7 \\
\hline 4. & $\begin{array}{l}\text { Many requirements are needed to avail of start-up business } \\
\text { capital. }\end{array}$ & 24 & 24.7 \\
\hline 5. & $\begin{array}{l}\text { Information on blacklisted/suspended/canceled private } \\
\text { employment services is usually late }\end{array}$ & 21 & 21.6 \\
\hline 6. & $\begin{array}{l}\text { We are not aware of non-government organizations' } \\
\text { livelihood programs. }\end{array}$ & 21 & 21.6 \\
\hline 7. & My qualifications do not fit the vacancies available. & 20 & 20.6 \\
\hline 8. & Most of the vacancies are managerial positions. & 18 & 18.6 \\
\hline 9. & Job fairs are very seldom. & 18 & 18.6 \\
\hline 10. & There is no updated registry of skills. & 15 & 15.5 \\
\hline 11. & There are no vacancies available for senior citizens. & 12 & 12.4 \\
\hline 12. & Training takes two (2) days long. & 10 & 10.3 \\
\hline 13. & $\begin{array}{l}\text { The self-employment program of the DOLE is not always } \\
\text { available. }\end{array}$ & 10 & 10.3 \\
\hline 14. & Self-employment assistance is not always available. & 9 & 9.3 \\
\hline 15. & Results of referrals conducted by the office are always late. & 9 & 9.3 \\
\hline 16. & There is no schedule for enhancement training. & 8 & 8.2 \\
\hline 17. & Jobs are not available for senior high school graduates. & 7 & 7.2 \\
\hline 18. & Referrals are always delayed. & 7 & 7.2 \\
\hline 19. & $\begin{array}{l}\text { My child was not accepted into the Summer Job program of } \\
\text { the city. }\end{array}$ & 6 & 6.2 \\
\hline 20. & No available job positions for women. & 4 & 4.1 \\
\hline 21. & There is no vocational and technical training. & 4 & 4.1 \\
\hline 22. & I am overqualified. & 2 & 2.1 \\
\hline
\end{tabular}


Many requirements are needed to avail of start-up business capital obtained a count of 24 out of 119 total respondents or $24.7 \%$.

In accordance with Sec. 5 of Chapter 2 of the Government Accounting Manual (GAM) prescribed by the Commission on Audit (COA) pursuant to the 1987 Constitution of the Republic of the Philippines, claim against government funds should be supported by complete documentation; hence, the release of start-up capital for the availment of this project needs documentation, which respondents found challenging.

\section{Challenges encountered by local business establishments}

Table 6 presents the challenges encountered by local business establishments in the implementation of services by the PESO. The major challenge identified was not being aware of NGOs ' livelihood programs which maybe they can coordinate. No updated registry of skills where business establishments can refer to in their recruitment is another challenge, supporting the study of Wickramasekara (2019) that there is no effective information dissemination system initiated by the government nor by NGOs.

Table 6. Challenges Encountered by Business Establishments on the implementation of the Services of the Public Employment Service Office

\begin{tabular}{|c|c|c|c|}
\hline & Challenges & $f$ & $\%$ \\
\hline 1. & $\begin{array}{l}\text { We are not aware of non-government organizations' livelihood } \\
\text { programs. }\end{array}$ & 7 & 31.8 \\
\hline 2. & There is no updated registry of skills & 5 & 22.7 \\
\hline 3. & $\begin{array}{l}\text { Information on blacklisted/suspended/canceled private employment } \\
\text { services is usually late }\end{array}$ & 4 & 18.2 \\
\hline 4. & There is no vocational and technical training. & 4 & 18.2 \\
\hline 5. & There are recruiters who charge local employment services for a fee. & 3 & 13.6 \\
\hline 6. & The self-employment program of the DOLE is not always available & 2 & 9.1 \\
\hline 7. & Job fairs are very seldom & 2 & 9.1 \\
\hline
\end{tabular}

While four representing $18.2 \%$ of the business establishments mentioned that information on blacklisted/suspended/canceled employment agencies always comes late and there are no vocational and technical training which affirmed the study of Hatsukano (2019) on the need for information needed by business establishments. Only two representing $9.1 \%$ of businesses recognized the absence of DOLE's self-employment programs and the conduct of job fairs by the PESO as very rare.

\section{Challenges on the implementation of special employment services}

Table 7 presents the challenges encountered by respondent overseas job seekers concerning the implementation of special employment services by the PESO.

The top five challenges are: seminars for re-skilling or skills enhancement for career shift/change are seldom; hard to avail employment assistance; job fairs for OFWs are rare; difficulty to attend the schedule of training of unemployed OFWs; I have to qualify to avail the self-employment programs of non-government institutions; recipients of the financial assistance from the city government are pre-identified, and pre-departure loan assistance program is not widely disseminated.

These special employment services, most of which are on training, were conducted by the PESO, while some were in partnership with the Department of Trade and Industry (DTI), OWWA, POEA, and the DAR. These challenges are recognized in the study of Roldan (2020), who concluded that despite programs being implemented for overseas Filipino workers and returning migrants, the study found that further government intervention should be done, such as information dissemination through social media, mentoring, and follow-up training, provision of non-collateral loans, and assistance in creating value networks for OFWs which had become more relevant due to the current pandemic. 
Table 7. Challenges encountered by Overseas Jobseekers on the Implementation of Special Employment Services

\begin{tabular}{lcc}
\hline \multicolumn{1}{c}{ Challenges } & $\mathrm{f}$ & $\%$ \\
\hline 1. Seminars that provide reskilling or skills enhancement for career shift or & 7 & 36.8 \\
change are seldom. & 6 & 31.6 \\
2. It is hard to avail of employment assistance & 6 & 31.6 \\
3. It is hard to attend to the schedule of training of unemployed OFWs. & 6 & 31.6 \\
4. Job fairs for OFWs are very rare. & 4 & 21.1 \\
5. I have to qualify to avail the self-employment program of a non- & & \\
$\quad$ government institution. & 4 & 21.1 \\
6. The schedule for the career guidance training is not posted on bulletin & & \\
boards. & 4 & 21.1 \\
7. Recipients of the financial assistance from the city government are pre- & 3 & 15.8 \\
$\quad$ & 2 & 10.5 \\
identified. & 2 & 10.5 \\
9. I was not identified as a recipient of the BALIK assistance program. & 2 & 10.5 \\
10. The schedule for the specialized training is not disseminated. & 1 & 5.3 \\
11. The pre-departure loan assistance program is not widely disseminated. & 2 \\
12. I was not informed of values development activities. & & \\
\hline
\end{tabular}

\section{Challenges encountered by overseas employment agencies}

Table 8 presents the challenges encountered by overseas employment agencies. The first two challenges identified by overseas employment agencies are deficiencies in the implementation of employment services, such as "there are recruiters who charge recruitment services for a fee" and "information on blacklisted/suspended/canceled private employment services are late." Pursuant to RA 8579 as amended by RA 10691 or the Public Employment Service Act of the Philippines, penalties of suspension and cancellation of licenses shall be implemented by LGUs in coordination with the DOLE. The other challenges were identified by a very small number of overseas employment agencies, with only one identifying four (4) challenges.

Table 8. Challenges encountered by Overseas Employment Agencies on the Implementation of Special Employment Services

\begin{tabular}{|c|c|c|c|}
\hline & Challenges & $\mathrm{f}$ & $\%$ \\
\hline 1. & $\begin{array}{l}\text { The seminar that provides reskilling or skills enhancement } \\
\text { for career shift/change are seldom }\end{array}$ & 5 & 55.6 \\
\hline 2. & It is hard to avail of employment assistance & 3 & 33.3 \\
\hline 3. & Job fairs for OFWs are very rare. & 3 & 33.3 \\
\hline 4. & $\begin{array}{l}\text { The pre-departure loan assistance program is not widely } \\
\text { disseminated. }\end{array}$ & 3 & 33.3 \\
\hline 5. & No information on self-employment programs. & 2 & 22.2 \\
\hline 6. & $\begin{array}{l}\text { I was not identified as a recipient of the BALIK Assistance } \\
\text { program. }\end{array}$ & 1 & 11.1 \\
\hline 7. & $\begin{array}{l}\text { I have to qualify to avail the self-employment program of } \\
\text { a non-government institution. }\end{array}$ & 1 & 11.1 \\
\hline 8. & I was not informed of values development activities. & 1 & 11.1 \\
\hline 9. & $\begin{array}{l}\text { Recipients of the financial assistance from the city } \\
\text { government are pre-identified. }\end{array}$ & 1 & 11.1 \\
\hline 10. & $\begin{array}{l}\text { The schedule for the specialized training is not } \\
\text { disseminated. }\end{array}$ & 0 & 00.0 \\
\hline 11. & $\begin{array}{l}\text { The schedule for the career guidance training is not } \\
\text { posted on bulletin boards. }\end{array}$ & 0 & 00.0 \\
\hline 12. & $\begin{array}{l}\text { It is hard to attend to the schedule of training of } \\
\text { unemployed OFWs. }\end{array}$ & 0 & 00.0 \\
\hline
\end{tabular}




\subsection{Conclusion}

Based on the findings, the government remains an effective implementer of programs and services to reduce unemployment, as revealed by the very high level of implementation in providing employment opportunities. Creating opportunities for steady employment through the PESO services is the best way for local governments to reduce unemployment, validating the theory of strong, sustainable development through good governance and support systems.

The challenges encountered by local and overseas jobseekers reflect the inadequacy of some services attributed to significant institutional weaknesses that lead to duplication of some programs, poor design and targeting of beneficiaries, and lack of monitoring of the impact of some programs on employment. Strong coordination with national government agencies and active partnership with the academe, civil society, and the private sector will enhance the implementation of the PESO services. Enactment of local laws is recommended to enhance employment facilitation by the local PESO.

\section{REFERENCES}

Anand, V. V., Shanthanlakshmi, M., Srinivasan, G. U., Arunkumar, V., Icewarya, G., Nandhu, S., \& Kamatchi, S. M. (2018). A Study on Effectiveness of Recruitment Organizational Support in ITes. International Journal of Pure and Applied Mathematics, 119(7), 2755-2764. https://www.acadpubl.eu/jsi/2018-119-7/articles/7c/89.pdf.

Angel-Urdinola, D. F., Kuddo, A., \& Semlali, A. (2012). Public Employment Services in the Middle East and North Africa. https://edmsp1.ilo.org/edmsp1/groups/skills/documents/skpcontent/ddrf/mdqw/ edisp/ wcmstest4_040633.pdf.

Asian Development Bank (ADB) (2018). Labor Market Programs in the Philippines. https://www.adb.org/sites/ default/files/linked-documents/49117-002-sd-04.pdf

Bachtiar, P. P., \& Prasetyo, D. D. (2014). The Return Migration and Various Reintegration Programs for Lowskilled Migrant Workers in Indonesia. SMERU Research Institute. https://media.neliti.com/media/ publications/51055-EN-the-return-migration-and-various-reintegration-programs-for-low-skilled-migrant. pdf.

Bangko Sentral ng Pilipinas (BSP) (2018). Report on Regional Economic Development in the Philippines 2018. https://www.bsp.gov.ph/Media_And_Research/Report\%20on\%20Regional\%20Economic\%20Developments/ REDP_2018.pdf.

Barr, J., \& Attrey, A. (2017). Building Local Responsiveness in Employment and Skills Systems in Southeast Asia: Lessons from Malaysia, the Philippines, Thailand, and Vietnam. https://doi.org/10.1787/8455fede-en.

Behrenz, L., Delander, L., \& Månsson, J. (2013). The Public Employment Service: A Survey of Cost-benefit Analysis and Productive Efficiency Analysis Studies. Linnéuniversitetet. https://www.diva-portal.org/smash/get/ diva2:677253/FULLTEXT01.pdf.

Berggren, C., \& Olofsson, A. (2019). A Societal Perspective on Self-employment-Sweden as an example. Studies in Higher Education, 1-13. https://doi.org/10.1080/03075079.2019.1688285.

Breaugh, J. (2013). Employee Recruitment. Annual Review of Psychology. Vol. 64. https://doi.org/10.1146/annurevpsych-113011-143757.

Caponi, V. (2017). Public Employment Policies and Regional Unemployment Differences. Regional Science and Urban Economics, 63, 1-12. http://hdl.handle.net/10419/103529.

Chemsripong, S. (2016). Skilled Labor Mobility in the ASEAN Economic Community (AEC): Experience from Thailand Labor Market. Journal of Economics and Political Economy, 3(4), 767-781. http://dx.doi. org/10.1453/jepe.v3i4.1012.

Congress of the Republic of the Philippines, 2017. Republic act 8759, otherwise known as the public employment service office act of 1999, as amended by RA 10691.

Cruz, K. (2014). Making It Happen: Career Guidance and Employment Coaching in the Philippines. Department of Labor and Employment (DOLE). https://wapes.org/en/system/files/philippines.pdf.

Cyrek, M., \& Fura, B. (2019). Employment for sustainable development: sectoral efficiencies in EU countries. Social Indicators Research, 143 (1), 277-318.

Department of Labor and Employment (DOLE) (2014). At JobStreet's Career Congress '11, Baldoz cites the need for 21st-century skills to address mismatch. https://www.dole.gov.ph/news/at-jobstreets-career-congress11-baldoz-cites-need-for-21st-century-skills-to-address-mismatch.

Department Order No. 157-16 Series of 2016. Implementing Rules and Regulations of Republic Act 8759, otherwise known as the Public Employment Service Act of 1999, as amended by Republic Act No. 10691.

Esser, F., \& Vliegenthart, R. (2017). Comprehensive research methods. The international encyclopedia of communication research methods, pp. 248-269.

Fonseca, J. R. (2015). A Public Administration Headache: An Evaluation Analysis of Prison Policy and Recidivism Toward Social Reintegration. International Journal of Public Administration, 38(10), 701-711. https://doi.org/ 10.1080/01900692.2014.955197. 
Foster-McGregor, N., Stehrer, R., \& de Vries, G. J. (2013). Offshoring and The Skill Structure of Labour Demand. Review of World Economics, 149(4), 631-662. https://doi.org/10.1007/s10290-013-0163-4.

Hatsukano, N. (2019). Returned Migrant Workers in Cambodia: Motivations for Moving and Economic Reintegration. Naomi Hatsukano, 57. https://www.eria.org/uploads/media/6.RPR_FY2017_19_Chapter_3.pdf.

International Labour Organization (ILO) (2013). Global Employment Trends 2013. https://www.ilo.org/wcmsp5/ groups/public/---dgreports/---dcomm/---publ/documents/publication/wcms_202326.pdf.

International Labour Organization (ILO) (2015). Informal Economy in the Philippines. https://www.ilo.org/manila/ areasofwork/informal-economy/lang--en/index.htm.

International Labour Organization (ILO) and International Training Center (ITC) 2018. Public Employment Services and Private Employment Agencies in a Changing Recruitment Landscape. https://www.ilo.org/wcmsp5/ groups/public/---ed_protect/---protrav/---migrant/documents/instructionalmaterial/wcms_682744.pdf.

International Labour Organization (ILO) (2020). 2030 Development Agenda: ILO Focus Targets. https://www.ilo. org/global/topics/sdg-2030/targets/lang--en/index.htm.

International Labour Organization (ILO) (2021). Public Employment Services. https://www.ilo.org/moscow/areasof-work/employment/WCMS_384570/lang--en/index.htm.

Johnson, R. R. \& Kuby, P. J. (2011). Elementary Statistics. Cengage Learning. http://sutlib2.sut.ac.th/sut_ contents/59767.pdf.

Karnani, A. (2011). Reducing Poverty through Employment. Innovations: Technology, Governance, Globalization, 6(2), 73-97. org/doi/pdf/10.1162/INOV_a_00071.

Karr, J., Lokshin, B., \& Loh, K. (2020). The Future of Work Across ASEAN: Policy Prerequisites for the Fourth Industrial Revolution. http://hdl.handle.net/11540/11663.

Kluve, J., Puerto, S., Robalino, D. A., Romero, J., Rother, F., Stöterau, J., Stoterau, J., Weidenkaff, F., \& Witte, M. (2016). Do youth employment programs improve labor market outcomes? A systematic review. http://dx.doi. org/10.4419/86788754.

Lichy, J., \& Khvatova, T. (2019). Rethinking Solutions for Re-balancing the Education-job Mismatch. Journal of Management Development. https://doi.org/10.1108/JMD-03-2018-0070

Nicavera, E. (2021). Labor, Business Groups in Negros Occidental Apprehensive over Higher Inflation. Sun Star Bacolod. https://www.sunstar.com.ph/article/1888072/Bacolod/Business/Labor-business-groups-in-NegrosOccidental-apprehensive-over-higher-inflation.

Nunn, A. (2012). Performance Management in Public Employment Services. The European Commission Mutual Learning Programme for Public Employment Services. http://ec.europa.eu/social/ BlobServlet?docId =14095\&langId =en.

Organization for Economic Co-operation and Development (OECD) (2015). G20 National Employment Plans: Proposed Self-Reporting Template. https://www.oecd.org/g20/topics/employment-and-social-policy/G20National-Employment-Plan-proposed-self-reporting-template.pdf.

Organization for Economic Co-operation and Development (OECD), Asian Development Bank. (2017). Employment and Skills Strategies in the Philippines. https://doi.org/10.1787/23112336.

Patacsil, F. F., \& Tablatin, C. L. S. (2017). Exploring the Importance of Soft and Hard Skills as perceived by IT Internship Students and Industry: A Gap Analysis. Journal of Technology and Science Education, 7(3), $347-$ 368. http://www.redalyc.org/articulo.oa?id=331152600006.

Phaphuangwittayakul, A., Saranwong, S., Panyakaew, S. N., Inkeaw, P., \& Chaijaruwanich, J. (2018). Analysis of Skill Demand in the Thai Labor Market from Online Jobs Recruitments Websites. In 2018 15th International Joint Conference on Computer Science and Software Engineering (JCSSE) (pp. 1-5). IEEE. https://doi.org/10.1109/ JCSSE.2018.8457393.

Philippine Statistics Authority (PSA). (2015). Highlights of the Philippine Population 2015 Census of Population. https://psa.gov.ph/content/highlights-philippine-population-2015-census-population.

Ravelo, J. L. (2019). In the Philippines, training a new generation of construction workers. Inside Development. https://www.devex.com/news/in-the-philippines-training-a-new-generation-of-construction-workers-95693.

Roldan, M. D. G. Z. (2020). Reintegrating Returning Overseas Filipino Workers through Entrepreneurship.https:// www.dlsu.edu.ph/wp-content/uploads/pdf/conferences/research-congress-proceedings/2020/SEP-02.pdf.

Rutkowski, Jan J. (2015). Employment and Poverty in the Philippines. World Bank, Washington, DC. (c) World Bank. https://openknowledge.worldbank.org/handle/10986/26320 License: CC BY 3.0 IGO.

Scarpetta, S., Keese, M., \& Lauringson, A. (2020). Public employment services in the frontline for job seekers, workers, and employers. http://hdl.voced.edu.au/10707/553416.

Shi, L., Han, L., Yang, F., \& Gao, L. (2019). The Evolution of Sustainable Development Theory: Types, Goals, and Research Prospects. Sustainability, 11(24), 7158. https://doi.org/10.3390/su11247158.

Sinha, V., \& Thaly, P. (2013). A Review on Changing Trends of Recruitment Practice to enhance the Quality of Hiring in Global Organizations. Management: Journal of Contemporary Management Issues, 18(2), 141-156. https://hrcak.srce.hr/112643.

Suárez, P., Cueto, B., \& Mayor, M. (2014). Effects of Public Employment Services on Labor Transitions: An Analysis for the Spanish Case. International Journal of Manpower. http://dx.doi.org/10.1108/IM-05-2014-0109.

Suárez, P., Mayor, M., Cueto, B., \& Salas-Olmedo, M. H. (2019). The Spatial Structure of the Labour Market across Public Job Centres. Does their accessibility matter? Papers in Regional Science, 98(3), 1359-1372. https://doi. org/10.1111/pirs.12414. 
United Nations (2015). The United Nations Development Strategy Beyond 2015. https://www.un.org/en/ development/desa/policy/cdp/cdp_publications/2012cdppolicynote.pdf.

Vehkasalo, V. (2020). Effects of Face-to-Face Counseling on Unemployment Rate and Duration: Evidence from a Public Employment Service Reform. Journal for Labour Market Research, 54(1), 1-14. https://doi. org/10.1186/s12651-020-00276-8.

Weishaupt, J. T. (2011). Social Partners and the Governance of Public Employment Services: Trends and Experiences from Western Europe. Geneva: ILO. http://www.flexworkresearch.org/uploads/publication/ document/4227/ILOwcms_156033.pdf.

Wickramasekara, P. (2019). Effective Return and Reintegration of Migrant Workers with Special Focus on the ASEAN Member States. the ILO ASEAN Triangle Project, International Labour Organization, Bangkok. https:// dx.doi.org/10.2139/ssrn.3579358

Yap, M. L. M., \& Watene, K. (2019). The Sustainable Development Goals (SDGs) and Indigenous Peoples: Another missed opportunity? Journal of Human Development and Capabilities, 20(4), 451-467. https://doi.org/10.10 80/19452829.2019.1574725

\section{Correspondence:}

ELMA B. BACHITA*

bachitaelma1023@gmail.com

https://orcid.org/0000-0003-1410-6378

MA. JOHANNA ANN R. BAYONETA

johannaannbayoneta@gmail.com

https://orcid.org/0000-0003-4539-0850

*Principal Correspondent 